\title{
Prevalence of Bacterial Contamination and Antimicrobial Susceptibility Pattern among Blood and Blood Components collected with and without diverging method at Armed Forces Comprehensive Specialized Hospital, Addis Ababa, Ethiopia
}

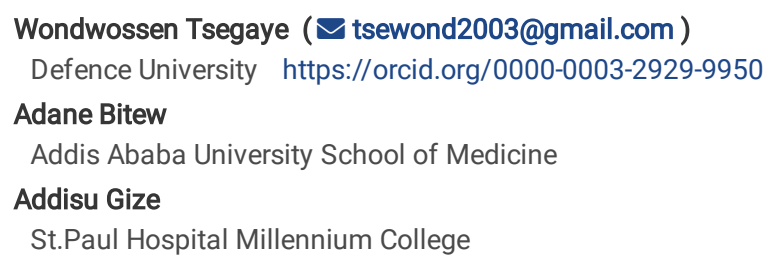




\section{Abstract}

Background: Transfusion of bacterial contaminated blood and blood components could be a cause of morbidity and mortality. Understanding the mechanism of blood contamination is important in developing infection control strategy.

Methods: A comparative cross-sectional study was done 376 blood and blood components collected with and without diverging method in Armed Forces Comprehensive Specialized Hospital. Then, Culturing of collected blood and blood components were inoculated in broth then subcultured on agar plate. And then, the drugs sensitivity test was done for each isolate. Bivariate analysis and multivariate logistic regression were used to infer association.

Results: The overall prevalence of bacterial contamination among blood and blood components were 17 (4.5\%). The prevalence of bacterial contamination of blood and blood components collected with the non-diverging and diverging method was $14(7.4 \%)$ and $3(1.6 \%)$ respectively with P value of 0.05 .

Staphylococcus epidermidis were the most dominate isolates. Gram positive isolates showed more than $74 \%$ sensitive for antibiotics and also became more than $9 \%$ resistant. Most gram negative isolates became sensitive but Pseudomonas aeruginosa showed resistant for Gentamicin. $29.4 \%(n=5 / 17)$ isolated bacteria were multidrug resistant.

Conclusion: There was a difference between bacterial contamination in blood and blood components collected between diverging and non-diverging blood collection methods.

\section{Introduction}

After the invention of blood circulation, the first recorded thriving blood transfusion was from dogs to dogs and then, lamb to human being. In the 1800 's, the blood transfusion was started among human beings then after the outcome became successful [1]. The stipulation of blood products in the US at the World War II and immediate to the postwar era were significantly increased. [2].

Blood transfusion is a medical mediation planned to offer protected blood products for those who need them [3]. Nevertheless, Transfusion transmittable infection can be transferred from blood products to recipients. Common TTI causative agents and bacteria can be screened from blood [4]. Bacterial contamination of blood products could be the causation for morbidity and mortality when transfused them to patients [5].

In the half of 1990s, both literature and organization's haemovigilance systems indicated case report about bacterial transmission and this interest depicted by the blood community [6]. Either skin commensals or gastrointestinal tract flora which accounts for $75 \%$ are the principal gram-positive aerobic pathogens [7].

Blood products may be infected during blood collection, inadequate disinfection of donor skin, processing and accident on blood bags. In addition to that, they also infected from asymptomatic bacteremia in the donor [8]. In developed countries, the incidence of bacterial contamination and its related transfusion transmittable bacterial infection (TTBI) has been greatly condensed as a result of proper donor screening [9], uses of enhanced donor skin decontamination method and diverting the first blood volume [10]. As opposed to developed countries, developing countries are not put into practice the above measures [8].

In African, the threat of bacterial contamination; gained through collection and processing, is 2500 times higher than developed countries. Moreover, visual examination of blood bags for hemolysis is the most common means of detecting for bacterial contamination [11]

The studies done in Ethiopia showed significant and variable prevalence of bacterial contaminations and their antimicrobial susceptibility pattern among whole blood collected by the non-diverging method $[11,12]$ were reported but not with diverging method. To this end, the aim of the current study was shown the prevalence of bacterial contamination of blood products collected by two different donor blood collection methods.

\section{Methods}

\section{Study area and population}

A comparative cross-sectional study was conducted from January 2017 to April 2018 in Armed Forces Comprehensive Specialized Hospital Addis Ababa, Ethiopia. The sample size was calculated based on two population proportion formula. The value of $P_{1}$ was taken as $15.33 \%$ ( 0.1533 ) [11] from the previous study on whole blood and $\mathrm{P}_{2}$ as $50 \%$. Considered $95 \%$ confidence interval and commonly used values for $\mathrm{C}_{\mathrm{p}}$, power; $\mathrm{C}_{0.05,95 \%}$, were 13 .

A total of 376 units of blood products were selected using convenient sampling method for blood culturing. Each unit of whole blood and PRBC was mixed before sampling with handshaking and striper and then we detached $20-25 \mathrm{~cm}$ segment after sealed the tubing at 5-10 cm away from the end of each blood bag's tubing. Each detached segment was labeled with coded labeling paper. In the biological safety cabinet, each unit of FFP, platelet, and detached segment was decontaminated first using packed swab saturated with $70 \%$ isopropyl alcohol and waited for one minute and then with $2 \%$ tincture iodine then waited for three minutes. After decontaminated the sterilized brain-heart infusion broth (Oxoid, Basingstoke, UK) blood culture bottle stopper in the same way like above, $3 \mathrm{ml}$ of blood samples were drawn from each segment using sterile disposable syringe and then dispensed into $15 \mathrm{ml}$ of BHI broth aseptically. The specimens were delivered to the AFCSH Microbiology laboratory incubation room then isolated, identified and tested for susceptibility [13].

The inoculated $\mathrm{BHI}$ was incubated at $37^{\circ} \mathrm{C}$ aerobically then observed daily for any possible signs of bacterial growth such as pellicle formation, hemolysis, gas formation clotting and turbidity for 7 days. After overnight incubation, the BHI bottles were mixed then one ml blood sample was taken from the bottle with a sterile disposable syringe and subculture two drops of sample on sheep Blood agar plate (BAP), MacConkey agar plate (MAP) and Chocolate agar plate (CAP) blindly. Inoculated BHI bottles; that show bacterial growth at 2 to 7 days, were also subcultured on sheep BAP, MAP, and CAP and also resubcultured 
until we got the pure colony. The inoculated MAP was incubated aerobically but BAP and CAP were incubated with $5-10 \% \mathrm{CO}_{2}$ atmosphere. Whenever bacterial growth was observed on the incubated media, identification of bacterial species was done based on bacterial cultural characteristics, gram stain and biochemical tests. The biochemical tests were done depending on their gram reaction result. For gram-positive bacteria, we used catalase, coagulase, CAMP, bile esculin, novobiocin, TSI tests and so on. We also used for gram-negative bacteria TSI, citrate, indole, motility, urease, and oxidase. The result of biochemical referred to the chart of gram-negative and positive bacteria to identify the species level of the bacteria. In addition, differential media like Mannitol salt agar was used to differentiate staphylococci species [14].

The antibiotic susceptibility testing was performed according to Kirby-Bauer disk diffusion method on Mueller hinton agar plates (MHA). Antibiotics were selected based on the recommendation of clinical and laboratory standards institute guideline (CLSI). The known volume and concentration of recommended antibiotics for gram-positive bacteria such as Amikacin $(30 \mu \mathrm{g})$ Cefoxitin $(30 \mu \mathrm{g})$, Clindamycin $(2 \mu \mathrm{g})$, Erythromycin (15 $\mu \mathrm{g})$, Penicillin (10 units), ), Gentamicin $(10 \mu \mathrm{g})$, Trimethoprim-sulphamethoxazole $(1.25 / 23.75 \mu \mathrm{g})$, Tobramycin $(10 \mu \mathrm{g})$ Ceftriaxone $(30 \mu \mathrm{g})$, Ampicillin $(10 \mu \mathrm{g})$, Chloramphenicol $(30 \mu \mathrm{g})$ and Cefotaxime $(30 \mu \mathrm{g})$ and also antibiotics for gram-negative bacteria like Amikacin $(30 \mu \mathrm{g})$, Amoxicillin + clavuninic acid $(10 / 20 \mu \mathrm{g})$, Cefepime $(30 \mu \mathrm{g})$, Ceftriaxone $(30 \mu \mathrm{g})$, Ciprofloxacin $(5 \mu \mathrm{g})$, Gentamicin $(10 \mu \mathrm{g})$, Meropenem $(10 \mu \mathrm{g})$, Piperacillin-tazobactam $(10 / 100 \mu \mathrm{g})$, Tobramycin $(10 \mu \mathrm{g})$ and Trimethoprim-sulphamethoxazole $(1.25 / 23.75 \mu \mathrm{g})$ were used. The zone of inhibition of those drugs was measured after $18-24 \mathrm{hr}$ inculcation to the adjacent millimeter of the caliper. Interpretation of identified bacteria as susceptible, intermediate, or resistant according to the recent CLSI specified interpretive criteria [15].

Quality control strains such as Geobacillus stermophilus (ATCC 7953), Staphylococcus aureus (ATCC 25923), Staphylococcus epidermidis (ATCC 12228), Escherichia coli (ATCC 25922), Pseudomonas aeruginosa (ATCC 27853), Enterococcus faecalis (ATCC 29212), Streptococcus pyogenes (ATCC 19615), Proteus mirabilis (ATCC 35659) and Klebssiella pneumonia (ATCC 13883) were used. Data were analyzed by Statistical Package for Social Sciences (SPSS) software version 20.0. (IBM, USA). Descriptive statistics were computed and data were presented using tables.

\section{Results}

In this study, we included 376 blood samples from blood products which were collected by non-diverging and diverging blood donor collection methods and delivered to AFCSH with equal proportion. Of this, O blood group with Rh-positive was the highest to be examined 137, (36.4\%). the minimum and maximum storage temperatures for whole blood were 3.5 and $5^{\circ} \mathrm{C}$, PRBC 3.5 and $4.8^{\circ} \mathrm{C}$, FFP -40 and $-38^{\circ} \mathrm{C}$ and also platelet 23 and $25^{\circ} \mathrm{C}$. Among the different types of blood products, majority of the storage time of whole blood, PRBC, FFP and platelet were at up to 1 week $26(27.7 \%), 1-2$ week $51(54.3 \%)$, more than six weeks $30(31.9 \%)$ and $1-5$ days $94(100 \%)$ respectively.

The overall prevalence of bacterial contamination among blood products were 17(4.5\%). Among the blood products, whole blood and PRBC took the highest bacterial contamination growth 6 (35.3\%). In addition, the most contaminated blood group type was 0 Rh-positive 6 (35.3\%). From the overall prevalence of bacterial contamination $(\mathrm{N}=17 / 376,4.5 \%)$, gram-positive and negative were isolated. Of these, gram-positive bacteria $(\mathrm{N}=14 / 17,82.4 \%)$ took the largest number and gram-negative bacteria accounted $(\mathrm{N}=3 / 17,17.6 \%)$. Among the isolated gram-positive bacteria Staphylococcus epidermidis ( $\mathrm{N}=6,35.3 \%)$ became the dominant isolate followed by Staphylococcus aureus $(\mathrm{N}=4,23.5 \%)$.

The prevalence of bacterial contamination from those blood products which were collected with non-diverging 7.4\% $(n=14 / 188)$ was higher than diverging method 1.6\% ( $n=3 / 188)$. There was a statistical significant association between blood donor collection method and bacterial contamination (AOR (CI): 7.8 (160.1), P value: 0.05). Refer Table 1.

The most isolated bacteria from blood products collected with non-diverging method were Staphylococcus epidermidis $(\mathrm{n}=4,28.57 \%)$ and Staphylococcus aureus $(n=4,28.57 \%)$. Whereas identified isolates from blood and blood components collected with diverging method were only Staphylococcus epidermidis $(n=2,66.7 \%)$.

Among gram positive bacteria such as Staphylococcus aureus, Staphylococcus epidermidis Listeria monocytogenes Listeria species which were isolated from those blood products collected with non-diverging method. The most sensitive antibiotics for the identified isolates were Ceftriaxone (100\%), Ampicilin (100\%), Tobramycin (100\%) and Cefotaxime (100\%). The highest resistant antibiotics were Trimethoprim-sulphamethoxazole (27\%), Erythromycin (27\%),. Similarly, gram-negative isolates were sensitive for the antibiotics such as Amoxicillin + clavulanic acid (100\%), Piperacillin-tazobactam (100\%), Cefepime (100\%), Ceftriaxone (100\%), Tobramycin (100\%), Amikacin (100\%), Ciprofloxacin (100\%) and Trimethoprim-sulphamethoxazole (100\%). The only antibiotic that showed resistant to Pseudomonas aeruginosa 33.3\% was Gentamicin. Refer Table 2 and 3

Staphylococci epidermidis and Listeria spp were isolated from blood and blood components collected with diverging blood collection method. Most antibiotics were sensitive for these organisms except Ceftriaxone (100\%), Chloramphenicol (100\%) were intermediate. In addition, Trimethoprimsulphamethoxazole (67\%) was the most resistant antibiotic. Refer Table 4

Finally, among the isolated seventeen organisms, 5(29.4\%) were shown to be Multidrug resistant (MDR $\geq 2$ drugs) for one group of spectrum of antibiotics. Staphylococci epidermidis 3(17.6\%) took the highest MDR bacteria. Refer Table 5 
Table 1

Prevalence of overall bacterial contamination and association factors among collection method, blood and blood components in AFCSH Addis Ababa city, Ethiopia, January to April 2018.

\begin{tabular}{|c|c|c|c|c|c|c|c|}
\hline \multirow[t]{3}{*}{ Variables } & \multicolumn{2}{|c|}{ Bacterial } & Total & \multirow[t]{2}{*}{ COR (Cl) } & \multirow[t]{2}{*}{$P$ value for COR } & \multirow{2}{*}{$\begin{array}{l}\text { AOR } \\
\text { (Cl) }\end{array}$} & \multirow{2}{*}{$\begin{array}{l}P \text { value } \\
\text { for } A O R\end{array}$} \\
\hline & G & NG & $\mathbf{N}(\%)$ & & & & \\
\hline & $N(\%)$ & $N(\%)$ & & & & & \\
\hline
\end{tabular}

\begin{tabular}{|c|c|c|c|c|c|c|c|c|}
\hline \multirow{2}{*}{$\begin{array}{l}\text { Donor blood } \\
\text { collection } \\
\text { method }\end{array}$} & $\begin{array}{l}\text { Non- } \\
\text { diverging }\end{array}$ & $14(7.4)$ & 174 (92.6) & $188(50)$ & $4.96(1.4-17.6)$ & \multirow[t]{2}{*}{0.013} & $7.75(1-60.1)$ & \multirow[t]{2}{*}{0.05} \\
\hline & Diverging & $3(1.6)$ & 185 ( 98.4) & $188(50)$ & 1 & & 1 & \\
\hline \multirow{4}{*}{$\begin{array}{l}\text { Blood \& } \\
\text { blood } \\
\text { components }\end{array}$} & WB & $6(35.3)$ & $88(24.5)$ & $94(25)$ & $2.07(0.5-8.53)$ & 0.31 & & \\
\hline & PRBC & $6(35.3)$ & $88(24.5)$ & $94(25)$ & $2.07(0.5-8.53)$ & 0.31 & & \\
\hline & Platelet & 3 (17.6) & 91 (25.3) & $94(25)$ & $0.66(0.1-4.04)$ & 0.65 & & \\
\hline & FFP & $2(11.8)$ & $92(25.6)$ & $94(25)$ & 1 & & 1 & \\
\hline Total & & $17(100)$ & 359 (100) & $376(100)$ & & & & \\
\hline
\end{tabular}

Table 2

Antimicrobial susceptibility pattern of gram-positive bacteria isolated from blood culture among stored blood and blood components collected by non-divergir

\begin{tabular}{|c|c|c|c|c|c|c|c|c|c|c|c|c|c|c|c|c|c|c|c|c|}
\hline \multirow{4}{*}{$\begin{array}{l}\text { Bacterial } \\
\text { Isolates } \\
\text { Saureus }\end{array}$} & \multirow{4}{*}{$\begin{array}{l}\mathbf{N} \\
4\end{array}$} & \multirow{4}{*}{$\begin{array}{l}\text { P } \\
\\
S\end{array}$} & \multirow{2}{*}{\multicolumn{2}{|c|}{ GEN }} & \multirow{2}{*}{\multicolumn{2}{|c|}{ CTR }} & \multirow{2}{*}{\multicolumn{2}{|c|}{ CLD }} & \multirow{2}{*}{\multicolumn{2}{|c|}{ AMK }} & \multirow{2}{*}{\multicolumn{2}{|c|}{ CXT }} & \multirow{2}{*}{\multicolumn{2}{|c|}{ AMP }} & & & \multirow{2}{*}{\multicolumn{2}{|c|}{ PEN }} & & \\
\hline & & & & & & & & & & & & & & & \multicolumn{2}{|c|}{ COT } & & & \multicolumn{2}{|c|}{ ERY } \\
\hline & & & \multicolumn{2}{|c|}{$N(\%)$} & \multicolumn{2}{|c|}{$\mathrm{N}(\%)$} & \multicolumn{2}{|c|}{$N(\%)$} & \multicolumn{2}{|c|}{$\mathrm{N}(\%)$} & \multicolumn{2}{|c|}{$N(\%)$} & \multicolumn{2}{|c|}{$\mathrm{N}(\%)$} & \multicolumn{2}{|c|}{$N(\%)$} & \multicolumn{2}{|c|}{$N(\%)$} & \multicolumn{2}{|c|}{$N(\%)$} \\
\hline & & & 3 & (75) & ND & & 3 & $(75)$ & 3 & (75) & 4 & $(100)$ & ND & & 3 & (75) & 3 & $(75)$ & 3 & (75) \\
\hline & & 1 & 1 & $(25)$ & ND & & 1 & $(25)$ & 1 & $(25)$ & 0 & (0) & ND & & 1 & (25) & 0 & (0) & 0 & $(0)$ \\
\hline & & $\mathrm{R}$ & 0 & (0) & ND & & 0 & $(0)$ & 0 & $(0)$ & 0 & $(0)$ & ND & & 0 & $(0)$ & 1 & (25) & 1 & $(25)$ \\
\hline \multirow[t]{3}{*}{ S. epidermidis } & 4 & $S$ & 4 & $(100)$ & ND & & 4 & $(100)$ & 4 & $(100)$ & 2 & $(50)$ & ND & & 2 & $(50)$ & 3 & (75) & 2 & (50) \\
\hline & & I & 0 & (0) & ND & & 0 & $(0)$ & 0 & (0) & 0 & $(0)$ & ND & & 0 & (0) & 0 & (0) & 1 & (25) \\
\hline & & $\mathrm{R}$ & 0 & $(0)$ & ND & & 0 & $(0)$ & 0 & $(0)$ & 2 & $(50)$ & ND & & 2 & $(50)$ & 1 & $(25)$ & 1 & (25) \\
\hline \multirow[t]{3}{*}{ L.monocytogenes } & 2 & $S$ & 2 & $(100)$ & 2 & $(100)$ & ND & & ND & & ND & & 2 & $(100)$ & 1 & (50) & 2 & $(100)$ & 1 & (50) \\
\hline & & I & 0 & $(0)$ & 0 & (0) & ND & & ND & & ND & & 0 & (0) & 0 & $(0)$ & 0 & $(0)$ & 0 & $(0)$ \\
\hline & & $\mathrm{R}$ & 0 & $(0)$ & 0 & (0) & ND & & ND & & ND & & 0 & (0) & 1 & $(50)$ & 0 & (0) & 1 & $(50)$ \\
\hline \multirow[t]{3}{*}{ Listeria spp } & 1 & $S$ & 1 & $(100)$ & 1 & $(100)$ & ND & & ND & & ND & & 1 & $(100)$ & 1 & $(100)$ & 1 & $(100)$ & 1 & (100) \\
\hline & & I & 0 & $(0)$ & 0 & $(0)$ & ND & & ND & & ND & & 0 & $(0)$ & 0 & $(0)$ & 0 & $(0)$ & 0 & $(0)$ \\
\hline & & $\mathrm{R}$ & 0 & $(0)$ & 0 & $(0)$ & ND & & ND & & ND & & 0 & $(0)$ & 0 & $(0)$ & 0 & $(0)$ & 0 & $(0)$ \\
\hline \multirow[t]{3}{*}{ Sub Total } & 1 & $S$ & \multicolumn{2}{|c|}{$10(91)$} & 3 & (100) & 7 & (88) & 7 & (88) & 6 & (75) & 3 & $(100)$ & \multicolumn{2}{|c|}{$7(64)$} & 9 & (82) & \multicolumn{2}{|c|}{$7(64)$} \\
\hline & 1 & 1 & 1 & (9) & 0 & (0) & 1 & (22) & 1 & (22) & 0 & (0) & 0 & (0) & 1 & (9) & 0 & (0) & 1 & (9) \\
\hline & & $\mathrm{R}$ & 0 & (0) & 0 & $(0)$ & 0 & $(0)$ & 0 & $(0)$ & $2(2$ & & 0 & (0) & 3 & (27) & 2 & (18) & 3 & (27) \\
\hline Total & & & 11 & 100) & 3 & $(100)$ & 8 & $(100)$ & 8 & (100) & 8 & $(100)$ & 3 & $(100)$ & & 100) & 11 & (100) & 11 & $100)$ \\
\hline
\end{tabular}


Table 3

Antimicrobial susceptibility pattern of gram-negative bacteria isolated from blood culture among stored blood and blood components collected by non-diver AFCSH Addis Ababa city, Ethiopia, January to April 2018.

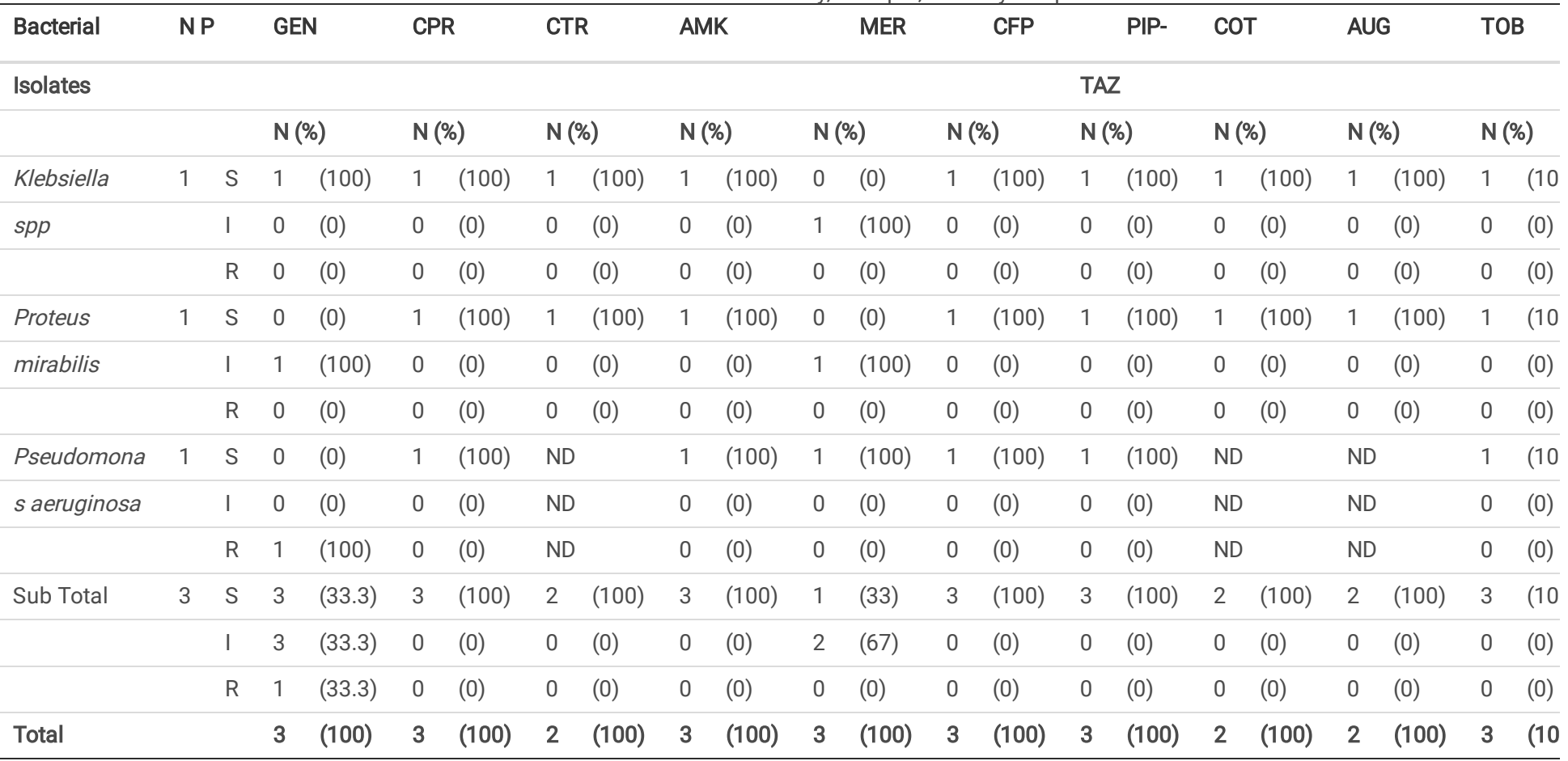

Key: $\mathbf{N}=$ Number $\mathrm{P}=$ Pattern ND = Not done GEN = Gentamicin CPR = Ciprofloxacin CTR = Ceftriaxone AMK = Amikacin MER = Meropenem CFP = Cefepime PIPTAZ = Piperacillin-tazobactam COT = Trimethoprim-sulphamethoxazole AUG = Amoxicillin + clavulanic acid TOB = Tobramycin S = Sensitive I = Intermediate R $=$ Resistant

Table 4

Antimicrobial susceptibility pattern of gram-positive bacteria isolated from blood culture among stored blood and blood components collected by diverging

\begin{tabular}{|c|c|c|c|c|c|c|c|c|c|c|c|c|c|c|c|c|c|c|c|c|c|}
\hline \multirow{3}{*}{$\begin{array}{l}\text { Bacterial } \\
\text { Isolates } \\
\text { S. } \\
\text { epidermidis }\end{array}$} & \multirow{3}{*}{$\begin{array}{l}\mathbf{N} \\
2\end{array}$} & \multirow[t]{3}{*}{$P$} & \multirow{2}{*}{\multicolumn{2}{|c|}{$\begin{array}{l}\text { GEN } \\
\mathrm{N}(\%)\end{array}$}} & \multirow{2}{*}{\multicolumn{2}{|c|}{$\begin{array}{l}\text { CTR } \\
\mathrm{N}(\%)\end{array}$}} & \multirow{2}{*}{\multicolumn{2}{|c|}{$\begin{array}{l}\text { CLD } \\
\mathrm{N}(\%)\end{array}$}} & \multirow{2}{*}{\multicolumn{2}{|c|}{$\begin{array}{l}\text { AMK } \\
\mathrm{N}(\%)\end{array}$}} & \multirow{2}{*}{\multicolumn{2}{|c|}{$\begin{array}{l}\text { CXT } \\
\mathrm{N}(\%)\end{array}$}} & \multirow{2}{*}{\multicolumn{2}{|c|}{$\begin{array}{l}\text { AMP } \\
\mathrm{N}(\%)\end{array}$}} & \multirow{2}{*}{\multicolumn{2}{|c|}{$\begin{array}{l}\text { COT } \\
\mathrm{N}(\%)\end{array}$}} & \multirow{2}{*}{\multicolumn{2}{|c|}{$\begin{array}{l}\text { PEN } \\
\mathrm{N}(\%)\end{array}$}} & \multirow{2}{*}{\multicolumn{2}{|c|}{$\begin{array}{l}\text { ERY } \\
\mathrm{N}(\%)\end{array}$}} & \multirow{2}{*}{$\begin{array}{c}\text { TOB } \\
\mathrm{N}(\%)\end{array}$} \\
\hline & & & & & & & & & & & & & & & & & & & & & \\
\hline & & & 2 & (100) & ND & & 1 & (50) & 2 & (100) & 2 & (100) & ND & & 1 & (50) & 2 & (100) & 1 & (50) & 2 \\
\hline & & I & 0 & $(0)$ & ND & & 0 & (0) & 0 & $(0)$ & 0 & (0) & ND & & 0 & (0) & 0 & (0) & 0 & (0) & 0 \\
\hline & & $\mathrm{R}$ & 0 & $(0)$ & ND & & 1 & (50) & 0 & $(0)$ & 0 & $(0)$ & ND & & 1 & (50) & 0 & (0) & 1 & (50) & 0 \\
\hline Listeria spp & 1 & S & 1 & (100) & 0 & $(0)$ & ND & & ND & & ND & & 1 & (100) & 0 & (0) & 1 & (100) & 1 & $(100)$ & 1 \\
\hline & & I & 0 & $(0)$ & 1 & (100) & ND & & ND & & ND & & 0 & $(0)$ & 0 & (0) & 0 & $(0)$ & 0 & $(0)$ & 0 \\
\hline & & $\mathrm{R}$ & 0 & $(0)$ & 0 & $(0)$ & ND & & ND & & ND & & 0 & $(0)$ & 1 & (100) & 0 & $(0)$ & 0 & $(0)$ & 0 \\
\hline Sub Total & 3 & $S$ & 3 & (100) & 0 & (0) & 1 & (50) & 2 & (100) & 2 & (100) & 1 & (100) & 1 (3 & & 3 & (100) & $2(6$ & & 3 \\
\hline & & I & 0 & (0) & 1 & (100) & 0 & (0) & 0 & $(0)$ & 0 & $(0)$ & 0 & $(0)$ & 0 & (0) & 0 & (0) & 0 & $(0)$ & 0 \\
\hline & & $\mathrm{R}$ & 0 & $(0)$ & 0 & $(0)$ & 1 & (50) & 0 & $(0)$ & 0 & $(0)$ & 0 & $(0)$ & 2 & (67) & 0 & $(0)$ & 1 & (33) & 0 \\
\hline Total & & & 3 & (100) & 1 & (100) & 2 & (100) & 2 & (100) & 2 & (100) & 1 & (100) & 3 & (100) & 3 & (100) & 3 & (100) & 3 \\
\hline
\end{tabular}

Key: $\mathrm{N}=$ Number $\mathrm{P}=$ Pattern ND = Not done GEN = Gentamicin CTR = Ceftriaxone CLD = Clindamycin AMK = Amikacin CXT = Cefoxitin AMP = Ampicillin COT = Trimethoprim-sulphamethoxazole PEN = Penicillin ERY = Erythromycin TOB = Tobramycin CHL = Chloramphenicol CXM = Cefotaxime S = Sensitive I = Intermediate $\mathrm{R}=$ Resistant 
Table 5

Multidrug resistant level of isolated bacteria stored blood and blood components collected by non-diverging and diverging method in AFCSH Addis Ababa city, Ethiopia, January to April 2018.

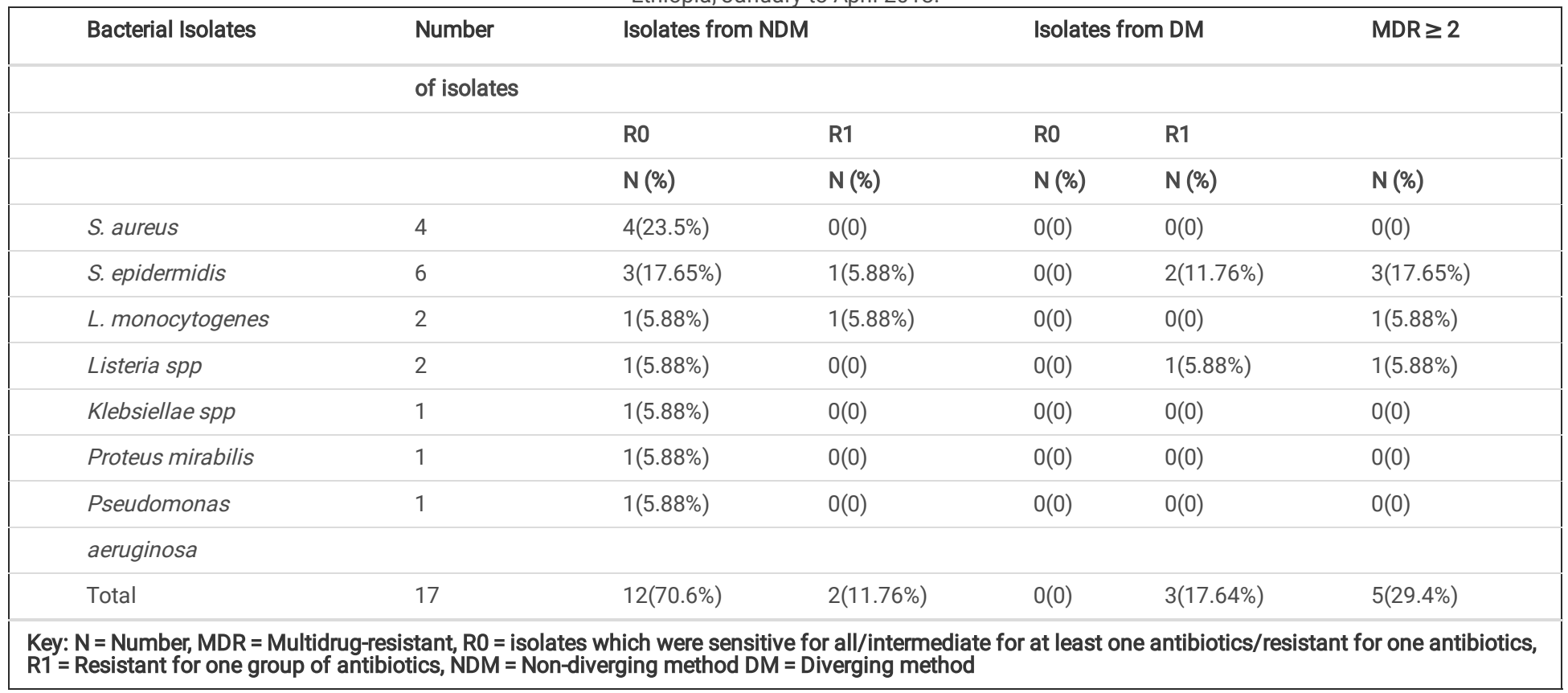

\section{Discussion}

The awareness of bacterial contamination among blood products which are used for blood transfusion as well as their sources of contamination is imperative for setting up the preventive measure at blood bank centers and blood transfusion centers. Moreover, it is significant to offer action and improve the blood collection practice, education and policy.

In our study, the overall prevalence of bacterial contamination among blood products was $4.5 \%(\mathrm{~N}=17 / 376)$. Blood group type $0+35.3 \%(\mathrm{~N}=6 / 17$, ) showed the most contaminated one. Studies from Debre Markos, Ethiopia carried out by Esmael A et al [12] also agreed with this study.

The prevalence of bacterial contamination among those blood products which were collected with non-diverging donor blood collection method was $7.4 \%$ ( $\mathrm{n}=$ 14/188) and almost close to previous studies reported from Africa countries like Ghana by Adjei A A et al 9\% $(n=28 / 303)$ [8] and Nigeria by Bolarinwa R A et al $8.8 \%$, $(n=14 / 162)$ [16]. The bacterial contamination of blood products collected with diverging done in this study is more or less similar to another finding like in Malaysia carried out by Jumaah $\mathrm{N}$ et al was $1.7 \%(n=12 / 702)$ [17].

Among the blood products, the highest bacterial contamination was observed in whole blood and PRBC. Another study was done in Ghana by Adjei A A. et al also supported that whole blood became the first to be contaminated in equal proportion except that PRBC is not included in their study [8].

The isolated bacteria in this study were both gram-positive bacteria (Staphylococcus aureus, Staphylococcus epidermidis, Listeria monocytogenes, and Listeria species) and gram-negative bacteria (Klebsiellae species, Proteus mirabilis and Pseudomonas aeruginosa). Our finding was agreed with different studies like in Nigeria by Bolarinwa R A et al [16] and India conducted by Barot T et al [18].

However, our finding was lower than studies done in Debre Markos, Ethiopia 12.5\% ( $n=15 / 120)$ ([2] and Gondar 15.3\% ( $n=21 / 137)$ [11] and also in Ghana $16.5 \%(n=16 / 97)$ [19], $17.5 \%(n=14 / 80)$ [20], this difference may be due to the difference in sample size, sample taken from only whole blood, the present study on the other hand higher in prevalence of bacterial contamination than other studies done in Zimbabwe 3.1\% $(n=6 / 196)$ [21], Uganda 3.5\% ( $n=18$ /510) [5]. The reason for increased prevalence may be in our countries the disinfection type is focused on application of $70 \%$ alcohol only.

The prevalence of bacterial contamination in the diverging method of the current study is higher than different countries finding such as New zealand done by Dickson M and Dinesh D was $0.04 \%(n=2378 / 59461)$ [22]. The difference may be the implementation of a compressive activity like proper donor screening, double disinfection, closed processing system and the existence of national haemovigilance programme in New zealand.

From this study; when we compared the bacterial contamination between blood donor collection methods of blood and blood components, the non-diverging method was higher than the diverging method one. In addition, the calculated adjusted odd ration became 7.8 so that the non-diverging blood donor collection method was likely more exposed to bacterial contamination by 7.8 times than diverging one.

Those blood products which were collected in both method share same conditions like application of single disinfection method, the absence of bacterial contamination screening and active national haemovigilance programme except changing the direction of the first 30-40 ml of blood into the diverging pouch. So, switching the first flow of blood reduced the contamination rate by $5.8 \%$. This concept is also supported by the reviewed study in Italy by Liumbruno $\mathrm{G} \mathrm{M}$ et al. The purpose of diverting the first 40-50 ml of donated blood to reduce the microbes or skin fragments especially comes from donor skin entering into the collection bag [23]. In addition, other study in Japan by Satake M et al also maintained that the positivity rate of bacterial contamination were 
$36 / 21786(0.17 \%)$ and $11 / 21783(0.05 \%)$ without and with diversion method in that order. Even if this study done in platelet concentrates only, used different methodology, sample volume and include anaerobic bacteria detection [24].

As opposed to the current study, a study done in Zimbabwe by Makuni $\mathrm{N}$ et al the finding of the highest contaminated among blood products was platelet $10.3 \%(n=4 / 36)$ followed by PRBC 1.3\% $(n=2 / 149)$. There was no unit of whole blood was contaminated by bacteria. The difference may be they took unequal amount of from each blood products by Makuni $\mathrm{N}$ et al [21].

Considering the drug resistance pattern, the finding s of this study was agreed with a study from Nigeria and they also reported that gram-positive bacteria were sensitive for Gentamicin and Ceftriaxone but the majority of the antibiotics were resistant [16]. The only antibiotic that showed resistant to the Pseudomonas aeruginosa was Gentamicin. Majority of the antibiotics were sensitive for Klebsiella spp and Proteus mirabilis. But a study from Debremarko indicated that all the gram-negative organisms isolated were resistant to Cotrimoxazole and susceptible to Ciprofloxacin and Cefoxicitin [12]. The levels of Multi drug resistant for one grouped drug spectrum (MDR $\geq 2$ drugs) were 5(29.4\%). In our study gram-positive bacteria showed MDR for chemically different drugs. Our finding was lower than Study done here in Gondar (66.7\%), Ethiopia by Wondimu $\mathrm{H}$ et al [11].

In conclusion, our study showed that the prevalence of bacterial contamination of stored blood products was higher in those collected with non-diverging method than diverging one. So, there was a difference between diverging and non-diverging blood collection method. Furthermore, Staphylococci epidermidis became the most commonly isolated bacteria. A considerable level of resistant bacteria and MDR organisms were observed. Therefore, blood bank should improve blood donor collection method from non-diverging to diverging method.

\section{Limitations}

This study couldn't identify anaerobic bacteria.

\section{Abbreviations}

AFCSH: Armed Forces Comprehensive Specialized Hospital; AST: Antimicrobial Susceptibility Test ; BAP: Blood Agar Plate

BHI: Brain-Heart Infusion ; CAP: Chocolate Agar Plate ; CLSI: Clinical and Laboratory Standards Institute

CNS Coagulase negative Staphylococci ;ENDFBBS: Ethiopia National Defense forces Blood bank service ; FFP: Fresh Frozen Plasma MAP: MacConkey Agar Plate ; PC: Platelet Concentrates ; PRBC: Packed Red Blood Cell; TSI: Triple sugar Iron test

TTBI Transfusion transmittable bacterial infection; TTI: Transfusion transmittable Infection

\section{Declarations}

\section{Competing interests}

The authors declare that they have no competing interests.

\section{Availability of data and materials}

The datasets used and/or analyzed during the current study are available from the corresponding author on reasonable request.

\section{Ethics approval}

The study was approved and given ethical clearance by ethics and research committee of the department of medical laboratory sciences, School of Allied Health, Sciences and College of Health Sciences of Addis Ababa University. Permission was obtained from the AFCSH administrator. Samples were coded and the confidentiality of donors' blood was maintained throughout the study. The permission is also involved to disseminate the findings of the study through a scientific workshop and publish in reputable journals.

\section{Funding}

None

\section{Consent for publications}

Not applicable.

\section{Acknowledgments}

The authors would like to Armed forces Compressive Specialized Hospital microbiology unit for providing laboratory space and facilities to conduct the experiments and its staffs who had been cooperative and supportive during specimen collection. 


\section{Authors' contributions}

WT and AB conceived and designed the experiments. WT performed the experiments. WT, AB, AG analyzed the data. WT and AG developed manuscript. All authors read and approved the final manuscript.

\section{References}

1. American Association of Blood Banks [internet]. Transfusion medicine: Highlights of transfusion medicine history; 2018 [Cited 2017 Aug 12 ]. Available from: http://www.aabb.org/tm/Pages/highlights.aspx.

2. Tobler LH, Busch MP. History of post transfusion hepatitis. ClinChem. 1997;43(8):1487-93.

3. SieJ N, Achila Okoth O, Issac J, Menghisteab E, Hailemariam M, Hagos S, et al. Seroprevalence of transfusion-transmissible infections among blood donors at National Blood Transfusion Service, Eritrea: a seven-year retrospective study. BMC infectious disease. 2018;18:1-9.

4. Jain R, Jain P, Mahadik V, Choudhury N. Prevalence and Incidence of Transfusion Transmitted Infections among VNRBDs in Central India. Natl J Integr Res Med. 2015;6(4):82-5.

5. Aloysius GBM, Joel B, Apecu R, Yap B, Byarugaba F. Bacterial Contamination of Blood and Blood Products at Mbarara Regional Blood Bank in Rural South Western Uganda. Scientific research journal. 2013;3:205-9. doi:10.4236/aid.2013.33030.

6. Mcdonald CP. Interventions Implemented to Reduce the Risk of Transmission of Bacteria by Transfusion in the English. National Blood Service. 2011;38:255-8. https://doi.org/10.1159/000330474.

7. Bihl F, Castelli D, Marincola F, Dodd Roger Y, Brander C. Transfusion transmitted infections. Journal of Translational Medicine. 2007;5(25):1-44. doi:10.1186/1479-5876-5-25.

8. Adjei AA, Kuma GK, Tettey Y, Ayeh-kumi PF, Opintan J, Apeagyei F, et al. Bacterial Contamination of Blood and Blood Components in Three Major Blood Transfusion Centers, Accra, Ghana. Jpn J Infect Dis. 2009;62:265-9.

9. Norfolk D, Handbook of Transfusion Medicine: 5th edition. United Kingdom: The stationary office (TSO); 2013.

10. Lee CC. Bacterial contamination of blood products. Hong Kong Red Cross Blood Transfusion Service, Hong Kong SAR, China. ISBT Science Series. 2011;6:427-31.

11. $10.1155 / 2013 / 308204$

Wondimu H, Addis Z, Moges F, Shiferaw Y Bacteriological Safety of Blood Collected for Transfusion at University of Gondar Hospital Blood Bank, Northwest Ethiopia. International Scholarly Research Notices. 2013; 2013:7 doi:10.1155/2013/308204.

12. Esmael A, Dagnew Z, Degu G. Bacterial Contamination of Stored Blood Ready for Transfusion at a Referral Hospital in Ethiopia. J Clin Res Bioeth. 2014;5(2):2-5. https://doi.org/10.4172/2155-9627.1000176.

13. Opoku-Okrah C, Feglo P, Amidu N, Dakorah MP. Bacterial contamination of donor blood at the Tamale Teaching Hospital, Ghana. African Health Sciences. 2009;9(1):13-8.

14. Tadesse A, Alem M. Medical Bacteriology. Gondar University: The Carter Center, USA; 2006.

15. Clinical and Laboratory Standards Institute guideline. Performance standard for antimicrobial susceptibility test. 27th ed.2017; 37 (1).

16. Bolarinwa Rahman A, Aboderin Oladipo A, Odetoyin Babatunde W, Adegunloye Aramide B. Bacterial contamination of blood and blood components in a tertiary hospital setting in Nigeria. International journal of infection control. 2011;7:1-6. doi:10.3396/ijic.V7i1.001.11.

17. Jumaah N, Joshi SR, Sandai D. Prevalence of Bacterial Contamination when using a Diversion Pouch during Blood Collection: A Single Center Study in Malaysia. 2014; 21(13): 47-53. [Cited 2017 Aug 12]. Available fromhttp://www.mjms.usm.my/notice/CURRENT\%20ISSUE\%20MJMS\%2021\% 283\%29/\%20mjms-21-3-047.pdf.

18. Barot T, Kothari F, Dighe M, Patel S. Prevalence of Bacterial Contamination of Stored Blood at Blood Bank S.S.G. Hospital, Vadodara. Int J Res Med. 2017; 5.

19. 4.: 77-80.e ISSN: $2320-2742$.

20. Boye A, Daniel D, Samuel A, James A. Peter Mate-Siakwa. Bacterial Contamination of at-Point-of Transfusion Blood in a Tertiary Hospital in Ghana. EC Bacteriology and Virology.2016:121-128.

21. Opoku-Okrah C, Feglo P, Amidu N, Dakorah MP. Bacterial contamination of donor blood at the Tamale Teaching Hospital, Ghana. African Health Sciences. 2009;9(1):13-8.

22. Makuni N, Simango C, Mavenyengwa Rooyen T. Brief Original Article Prevalence of bacterial contamination in blood and blood products at the National Blood Service Zimbabwe. 2015; 9: 421-424. doi:10.3855/jidc.5428.

23. Dickson M, Dinesh D. Bacterial contamination of platelet concentrate produced in New Zealand The New zeland medical journal.2013; 126 (1374):12-21.

24. Liumbruno GM, Catalano L, Piccinini V, Pupella S, Grazzini G. Reduction of the risk of bacterial contamination of blood components through diversion of the first part of the donation of blood and blood components, 2009; 7: 86-93. https://doi.org/10.2450/2008.0026-08.

25. Satake M, Mitani T, Oikawa S, Nagumo H, Sugiura S, Tateyama H, et al. Frequency of bacterial contamination of platelet concentrates before and after the introduction of diversion method in Japan. 2009; 49: 2152-2157. https://doi.org/10.1111/j.1537-2995.2009.02243.x. 